\title{
First Report of Eutetranychus banksi (McGregor) on Mahogany (Swietenia macrophylla King)
}

\section{Marcelo Tavares de Castro ${ }^{1}$ (i), Sandro Coelho Linhares Montalvão ${ }^{1}$ (i), Denise Navia $^{2}$ (1), Carlos Holger Wenzel Flechtmann ${ }^{3}$ (1), Rose Gomes Monnerat ${ }^{2}$}

\author{
${ }^{1}$ Universidade de Brasília (UnB), Brasília, DF, Brasil \\ ${ }^{2}$ Embrapa Recursos Genéticos e Biotecnologia, Brasília, DF, Brasil \\ ${ }^{3}$ Universidade de São Paulo (USP), Piracicaba, SP, Brasil
}

\begin{abstract}
Texas citrus mite, Eutetranychus banksi (McGregor) (Acari: Tetranychidae: Tetranychinae), considered a serious pest of the citrus crop in some countries, is reported for the first time on mahogany seedlings (Swietenia macrophylla King, Meliaceae) in Brazil, causing foliar tanning with chlorotic spots and premature fall of leaves.
\end{abstract}

Keywords: Texas citrus mite, acarology, forest pest. 
Mahogany (Swietenia macrophylla King), belonging to the family Meliaceae, is a tree species native to the Amazon region and greatly valued for its high quality wood. Large scale planting of this tree is limited due to the occurrence of Hypsipyla grandella Zeller (Lepidoptera: Pyralidae), whose caterpillar feeds mainly on the apical bud of the plant, causing bifurcations (Carvalho, 2007). Besides this insect, few organisms have been reported associated with mahogany. This paper aims to report on the occurrence of the Texas citrus mite, Eutetranychus banksi (McGregor) (Acari: Tetranychidae: Tetranychinae), on S. macrophylla leaves in Brasília, Federal District, Brazil.

When analyzing leaves of mahogany seedlings in a greenhouse with shade cloth as part of a study conducted in Brasilia (1543’49.8”S, 4753'59.1”'W), a large number of mites were found on the adaxial surface of the leaf. In total, 200 seedlings which were approximately eight months old were carried in vases contained PlantMax ${ }^{\circledast}$ substrate. The seedlings were watered daily and fertilized quarterly with

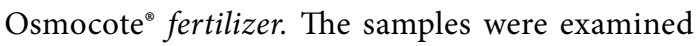

under a stereomicroscope, collected and preserved in Hoyer's medium on glass slides (Moraes \& Flechtmann, 2008). The mites were identified under the phase-contrast microscope and compared with the original description (McGregor, 1914, 1935). Voucher specimens were deposited in the Laboratory of Entomology and Acarology, ESALQ, Universidade de São Paulo, Piracicaba, São Paulo, Brazil.

The main damage caused by these mites is foliar tanning (Figure 1), with chlorotic spots and silvery appearance, due to the large amount of exuviae. Under intense attack, some leaves fall. Symptoms were observed most frequently on the lower portion of the seedlings, especially in the older leaves. In total, 53 seedlings were attacked by the mite (26,5\% of the seedlings).

Eutetranychus banksi was described by McGregor (1914) from Orlando, Florida, USA, associated with two hosts - Ricinus communis L. (Euphorbiaceae) and Mucuna pruriens (L.) DC. (Leguminosae). In Brazil, the species was first reported on citrus in Bahia (Bondar, 1928). It is currently known by more than 20 countries and 109 hosts (Migeon \& Dorkeld, 2017).
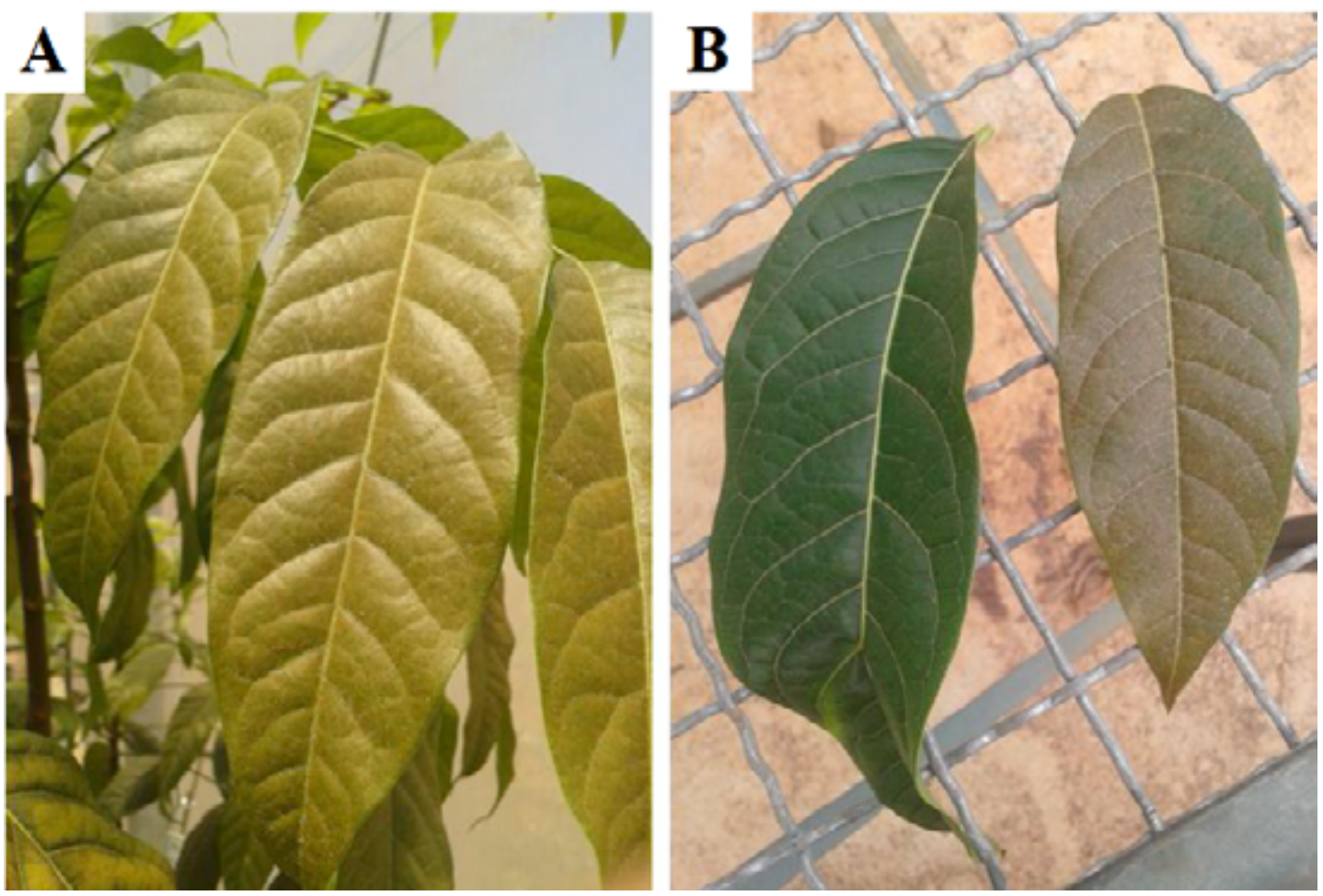

Figure 1. Eutetranychus banksi on mahogany leaves. A) Yellowing and leaf bronzing caused by the attack of E. banksi. B) Comparison between a healthy (left) and a damaged leaf (right). 

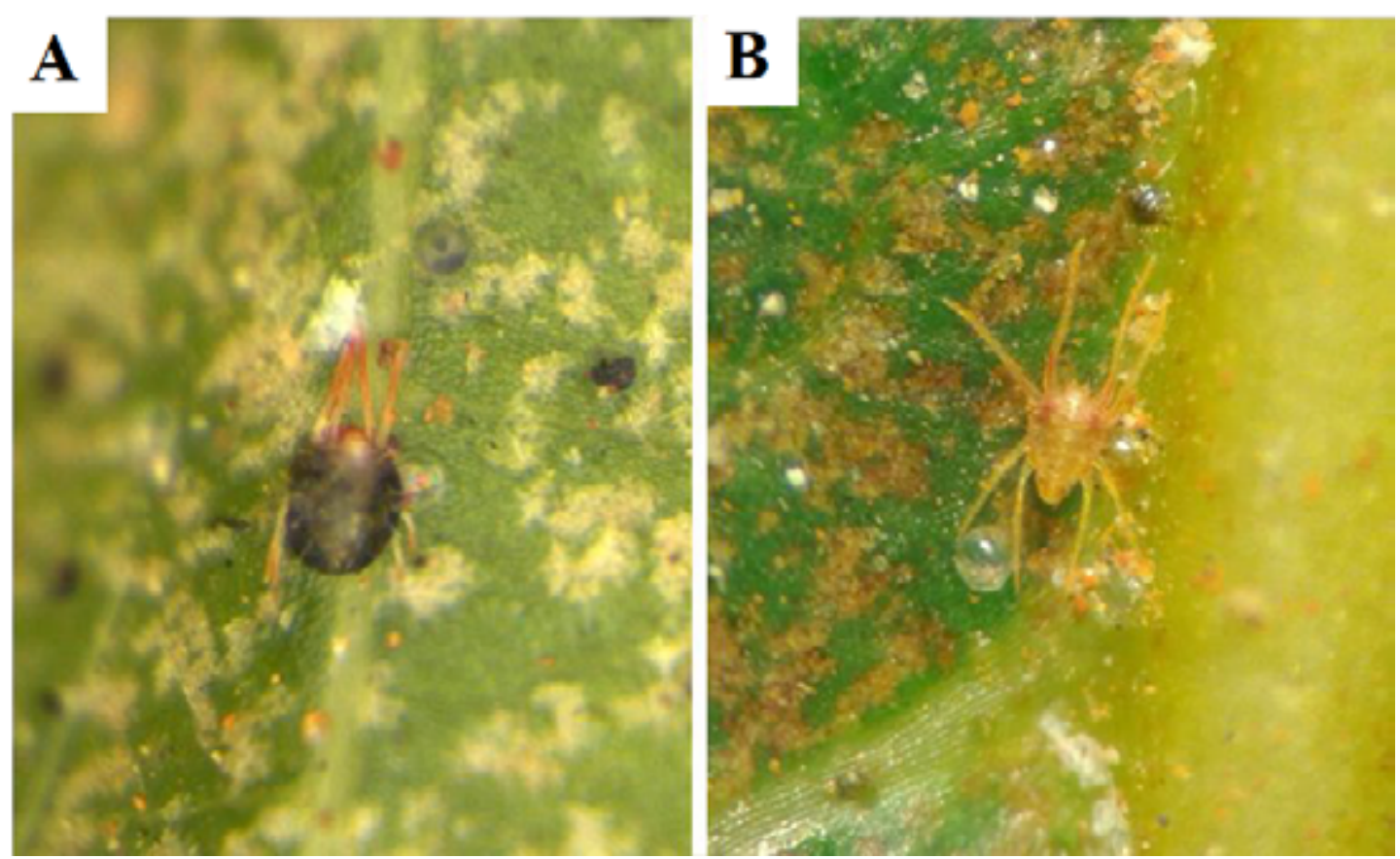

Figure 2. Female (A) and male (B) adults of Eutetranychus banksi on mahogany leaves.

The eggs of this mite are flat and disk-shaped with a thin edge. They range in color from light yellow to light green. Nymphs are very similar to females in shape and color. Females are broad, sturdy and flat, with moderately strong legs (Figure 2A). The coloration ranges from brownish green to dark brown, with greenish to brown dots and stripes near the lateral margins of the body. Males, on the other hand, have a triangular shaped body and are smaller than females, with slightly larger legs (Figure $2 \mathrm{~B}$ ). They range in coloration from bronzed to light brown with dark to greenish dots and stripes on the marginal side of the body.

Eutetranychus banksi presents a high morphological variation between populations and hosts, which often leads to erroneous identifications. In addition, variations may occur in the same population, especially in relation to the length and shape of the dorsal setae (Mattos \& Feres, 2009), thus being considered a polytypic species. E. orientalis Klein, 1936, is similar to E. banksi; still, the differences can be observed in the pattern distribution of the female idiosome dorsal setae $-E$. orientalis forms a square figure and $E$. banksi forms a trapeze figure - and in the legs $-E$. orientalis shows the insertion of the most dorsal setae on tubers (Ferragut et al., 2013).
This mite is considered a serious pest of the citrus and others crops (Moraes \& Flechtmann, 2008; Vacante, 2010) and it has already been registered on some hosts in Brazil besides citrus, including cultivated hosts like Ilex paraguariensis St. Hil. (Aquifoliaceae) and native hosts like Pachira aquatica Aubl. (Bombacaceae), causing yellowing leaf or no apparent damage (Ferla et al., 2005; Feres et al., 2009; Moraes \& Flechtmann, 2008). In the family Meliaceae, E. banksi has been found on Melia azedarach L. and Trichilia casaretti C. DC. in Brazil (Demite et al., 2013). This is the first report of this mite species on S. macrophylla.

\section{SUBMISSION STATUS}

Received: 8 Dec., 2017

Accepted: 24 Nov., 2018

\section{CORRESPONDENCE TO}

\section{Marcelo de Castro}

Universidade de Brasília (UnB), Faculdade de Agronomia e Medicina Veterinária (FAV), Ala centro do Instituto Central de Ciências (ICC), s/n, CEP 70910-970, Brasília, DF, Brasil e-mail: marceloengflorestal@gmail.com 


\section{FINANCIAL SUPPORT}

The authors are thankful for the Coordination for the Improvement of Higher Education Personnel (Capes) for the financial support.

\section{REFERENCES}

Bondar G. Relatório. Boletim do Laboratório de Patologia Vegetal 1928; 4: 39-46.

Carvalho PER. Mogno: Swietenia macrophylla. 2007 [cited 2019 May 22]. Available from: https://bit.ly/2W1L768

Demite PR, Lofego AC, Feres RJF. Mite (Acari: Arachnida) diversity of two native plants in fragments of a semideciduous seasonal forest in Brazil. Systematics and Biodiversity 2013; 11(2): 141-148. 10.1080/14772000.2013.806368

Feres RJF, Vieira MR, Daud RD, Pereira EG Jr, Oliveira GF, Dourado CL. Ácaros (Arachnida, Acari) de plantas ornamentais na região noroeste do estado de São Paulo, Brasil: inventário e descrição dos sintomas causados pelos fitófagos. Revista Brasileira de Entomologia 2009; 53(3): 466-474. 10.1590/S0085-56262009000300024

Ferla NJ, Marchetti MM, Siebert JC. Acarofauna (Acari) de erva-mate (Ilex paraguariensis St. Hil.: Aquifoliaceae) no estado do Rio Grande do Sul. Biociências 2005 [cited 2019 May 22]; 13(2): 133-142. Available: https://bit.ly/2Qm180B

Ferragut F, Navia D, Ochoa R. New mite invasions in citrus in the early years of the 21st century. Experimental and Applied Acarology 2013; 59: 145-164. 10.1007/s10493012-9635-9

Mattos VM, Feres RJF. Padrão morfológico e ciclo de vida de Eutetranychus banksi (Acari: Tetranychidae) de diferentes locais e hospedeiros. Zoologia 2009; 26(3): 427-442. 10.1590/S1984-46702009000300007

McGregor EA. Four new tetranychids. Annals of Entomological Society of America 1914; 7(4): 354-364. 10.1093/aesa/7.4.354

McGregor EA. The Texas citrus mite, a new species. Proceedings of the Entomological Society of Washington 1935 [cited 2019 May 24]; 37(8): 161-165. Available from: https://bit.ly/2VNhrVA

Migeon A, Dorkeld F. Spider Mites Web: a comprehensive database for the Tetranychidae. 2017 [cited 2017 Aug. 28]. Available from: https://bit.ly/2HS4Ye1

Moraes GJ, Flechtmann CHW. Manual de acarologia agrícola: acarologia básica e ácaros de plantas cultivadas no Brasil. Ribeirão Preto: Holos; 2008.

Vacante V. Citrus mites: identification, bionomy and control. Oxfordshire: CABI; 2010. 
Ahead of print 2019

In the manuscript "First Report of Eutetranychus banksi (McGregor) on Mahogany (Swietenia macrophylla King)”, DOI: https://doi.org/10.1590/2179-8087.119617, published in Floresta Ambient. 26, no 4.

\section{Instead of:}

Carlos Alberto Hector Flechtmann

ORCID: http://orcid.org/0000-0001-6693-3610

\section{Should read:}

Carlos Holger Wenzel Flechtmann

ORCID: https://orcid.org/0000-0001-7745-8544 